\title{
PENGARUH PROMOSI JABATAN DAN LINGKUNGAN KERJA TERHADAP KEPUASAN KERJA GURU PEGAWAI NEGERI SIPIL (STUDI PADA SMA NEGERI 6 KENDARI)
}

\author{
Muhamad Masri \\ Jurusan Manajemen Fakultas Ekonomi dan Bisnis Universitas Halu Oleo \\ masribones@gmail.com \\ Kendari - Indonesia
}

\begin{abstract}
The purpose of this study was to determine the effect of job promotion and work environment on the job satisfaction of Civil Servants (PNS) teachers in Kendari 6 High Schools (SMA), both simultaneously and partially. The sample in this study were all PNS teachers in SMA Negeri 6 Kendari, amounting to 57 people, the method of data collection using documentation and questionnaires. The measurement scale of the data used is the Likert scale and the data analysis method uses descriptive analysis method and multiple linear regression analysis. The results of this study indicate that simultaneous promotion of position and work environment has a positive and significant effect on job satisfaction of PNS teachers at SMA Negeri 6 Kendari. Likewise partially, the promotion of position and work environment has a positive and significant effect on job satisfaction of PNS teachers in SMA Negeri 6 Kendari.
\end{abstract}

Keywords: Job Promotion; Job Satisfaction; Work Environment

\begin{abstract}
Abstrak
Tujuan dari penelitian ini adalah untuk mengetahui pengaruh promosi jabatan dan lingkungan kerja terhadap kepuasan kerja guru PNS pada SMA Negeri 6 Kendari, baik itu secara simultan maupun secara parsial. Sampel dalam penelitian ini adalah seluruh guru PNS pada SMA Negeri 6 Kendari yang berjumlah 57 orang, metode pengumpulan data menggunakan dokumentasi dan kuesioner. Skala pengukuran data yang digunakan adalah skala likert serta metode analisis data menggunakan metode analisis deskriptif dan analisis regresi linear berganda. Hasil penelitian ini menunjukan bahwa secara simultan promosi jabatan dan lingkungan kerja berpengaruh positif dan signifikan terhadap kepuasan kerja guru PNS pada SMA Negeri 6 Kendari. Begitu juga secara parsial, promosi jabatan dan lingkungan kerja berpengaruh positif dan signifikan terhadap kepuasan kerja guru PNS pada SMA Negeri 6 Kendari.
\end{abstract}

Kata Kunci: Kepuasan Kerja; Lingkungan Kerja; Promosi Jabatan

Open Access at: http://ojs.uho.ac.id/index.php/PUBLICUHO/index

Journal Publicuho is licensed under a Creative Commons Attribution 4.0 International License. 


\section{PENDAHULUAN}

Organisasi merupakan kumpulan orang-orang yang memiliki visi dan misi yang sama untuk mencapai tujuan yang telah di tetapkan.faktor yang paling penting dalam suatu organisasi adalah sumber daya manusia yang sesuai dengan aktivitas dan kegiatan organisasi yang dijalankan.Sebuah organisasi atau perusahaan dapat meraih kesuksesan dengan adanya sumber daya manusia yang mempunyai peranan penting untuk mewujudkan hal tersebut.

SMA N 6 Kendari salah satu Sekolah Menengah Atas Negeri yang ada di Kecamatan Puuwatu Kota Kendari didirikan pada tahun 1987.SMA N 6 Kendari Merupakan salah satu sekolah yang memiliki standar yang tinggi dari beberapa sekolah negeri di Kota Kendari dan mempunyai banyak peminat setiap tahunnya. SMA N 6 Kendari memiliki akreditasi yang tinggi yaitu akreditasi A, tentunya akreditasi yang tinggi tersebut tidak bisa akan dicapai apabila pegawai tidak memiliki semangat kerja dan kepuasan kerja yang baik.

Berdasarkan observasi awal, penulis menilai bahwa terdapat beberapa masalah penentu kepuasan kerja guru PNS pada SMA Negeri 6 Kendari adalah (1).Promosi Jabatan, yaitu kurangnya peluang berkarier terhadap guru PNS; serta (2). Lingkungan kerja, yaitu proses belajar mengajar yang kurang efektif karena siswa-siswinya kurang perhatiannya pada saat proses belajar mengajar berlangsung sehingga kondisi kerja atau pengajar merasa tidak puas.Untuk mengetahui lebih jauh masalah tersebut maka kerja pegawai yang berkaitan dengan faktor-faktor kepuasan kerja perlu dilakukan.Berdasarkan uraian latar belakang di atas maka penulisi tertarik dan ingin mengetahui Faktor-faktor penentu kepuasan kerja Guru Pegawai Negeri Sipil pada SMA Negeri 6 Kendari. Olehnya itu penulis tertarik untuk mengkaji Pengaruh Promosi Jabatan dan Lingkungan Kerja terhadap Kepuasan Kerja Guru Pegawai Negeri Sipil (Studi pada SMA Negeri 6 Kendari.

Menurut Gibson, Invancevich san D onelly dalam Agus Dharma (1996 : 69) memberikan pengertian bahwa kepuasan kerja sebagai sikap yang dimiliki oleh seseorang mengenai pekerjaannya yang dihasilkan dari persepsi mereka yang didasarkan oleh faktorfaktor lingkungan kerja seperti gaya supervise yang diterima, prosedur dan kebijakan yang dikeluarkan, pengaruh antara karyawan dan pegawai, kondisi kerja dan lingkungan yang diperoleh. Sedangkan, Dawis dan Newstron, (1989) dikutip dari Rahmawati dan Widogdo, (2001) kepuasan kerja adalah seperangkat perasaan pegawai tentang menyenangkan atau tidaknya pekerjaan mereka.

Robert Hoppock dalam (Hoy, 2001:303) memberikan definisi kepuasan kerja sebagai kombinasi kondisi psikologis, fisiologis dan lingkungan yang menyebabkan orang berkata saya puas dengan pekerjaan saya.Maksudnya, kepuasan kerja adalah kondisi dimana individu menyukai pekerjaannya. Dengan demikian kepuasan kerja mencerminkan 


\section{Journal Publicuho}

ISSN 2621-1351 (online), ISSN 2685-0729 (print)

Volume 3 Number 3 (August-October), (2020) pp.349-360

perasaan seseorang terhadap pekerjaan yaitu carapandang pegawai terhadap pekerjaan mereka. Selanjutnya menurut Luthans ada lima factor kepuasan kerja yaitu (Komara dan Euis, 2014), yaitu: a) Pembayaran; b) Pekerjaan itu sendiri; c) Rekan Kerja; d) Promosi Pekerjaan; dan e) Kepenyeliaan/supervise.

Pada kajian ini, mencoba menganalisis apakah kepuasan kerja berkonstribusi atau berhubungan dengan promosi jabatan. Untuk memiliki pemahaman yang sama, menurut menurut Hasibuan (2005: 107) promosi jabatan adalah perpindahan yang memperbesar authority dan responsibility karyawan kejabatan yang lebih tinggi di dalam suatu organisasi sehingga kewajiban, hak, status dan penghasilannya semakin besar. Adapun pengertian promosi jabatan menurut Rivai (2004: 211) adalah apabila seorang karyawan dipindahkan dari satu pekerjaan kepekerjaan lain yang lebih tinggi dalam pembayaran, tanggung jawab dan atau level.

Promosi jabatan ini tidak lain yang menurut Hasibuan (2005: 113) menjelaskan bahwa tujuan dari promosi jabatan adalah sebagai berikut:

1. Untuk memberikan pengakuan, jabatan dan imbalan jasa yang semakin besar kepada karyawan yang berprestasi kerja tinggi.

2. Dapat menimbulkan kepuasan dan kebanggaan pribadi, status social yang semakin tinggi dan penghasilan yang semakin besar.

3. Untuk merangsang agar karyawan lebih bergairah bekerja, berdisiplin tinggi dan memperbesar produktivitas kerjanya.

4. Untuk menjamin stabilitas kepegawaian dengan direalisasikan promos kepada karyawan dengan dasar danpada waktu yang tepat serta penilaian yang jujur.

5. Kesempatan promosi dapat menimbulkan keuntungan berantai (Multilier effect) dalam perusahaan karena timbulnya lowongan berantai.

6. Memberikan kesempatan kepada karyawan untuk mengembangkan kreativitas dan inovasinya yang lebih baik demi keuntugan optimal perusahaan.

7. Untuk menambah dan memperluas pengetahuan serta pengalaman kerja para karyawan dan ini merupakan daya dorong bagi karyawan lainnya.

8. Untuk mengisi kekosongan jabatan karena pejabatnya berhenti. Agar jabatan itu tidak lowong maka dipromosikan karyawan lainnya.

9. Karyawan yang dipromosikan kepada jabatan yang tept, semangat, kesenangan dan ketenangannya dalam bekerja semakin meningkat sehingga produktivitas kerjanya juga meningkat.

10. Untuk mempermudah penarikan pelamar, sebab dengan adanya kesempatan promosi merupakan daya dorong serta perangsang bagi pelamar-pelamar untuk memasukan lamarannya. 
11. Promosi akan memperbaiki status karyawan dari karyawan sementara menjadi karyawan tetap setelah lulus dalam masa percobaannya.

Selanjutnya, indikator promosi jabatan menurut Tambunan (2012; dalam penelitian Eka 2015: 19) menentukan promosi jabatan dapat diukur dengan 4 indikator sebagai berikut: 1) penghargaan atasan atas kerja keras; 2) peniaian hasil kerja tahunan; 3) pemberian jabatan dan 4) penghargaan rekan kerja.

Posisi seseorang atau pegawai dalam melaksanakan tugas pokok dan fungsinya termasuk memperoleh amanah pada sebuah jabatan, terkadang dipengaruhi oleh lingkungan kerja dimana mereka beraktivitas. Menurut Sedarmayanti (2012:21) Lingkungan Kerja adalah keseluruhan alat perkakas dan bahan yang dihadapi lingkungan sekitarnya dimana seorang bekerja, metode kerjanya, serta pengaturan kerjanya baik sebagai perseorangan ataupun sebagai kelompok. Lingkungan kerja merupakan faktor-faktor yang berada disekitar manusia, baik fisik maupun non fisik dalam suatu organisasi.Faktor fisik ini mencakup peralatan kerja, suhu di tempat kerja, kesesakan dan kepadatan, kebisingan, serta luas ruang kerja.Sedangkan non fisik mencakup hubungan kerja yang terbentuk di instansi antara atasan dan bawahan serta antara sesama pegawai.Lingkungan kerja sangat berpengaruh besar dalam pelaksanaan penyelesaian tugas.

Lingkungan kerja Menurut Sedarmayati (2001: 2) adalah"Keseluruhan alat perkakas dan bahan yang dihadapi, serta lingkungan sekitarnya di mana seseorang bekerja, metode kerjanya, serta pengaturan kerjanya baik sebagai perseorangan maupun sebagai kelompok". Lingkungan kerja yang baik dapat menciptakan hubungan kerja yang bagus yang akan mengikat antara orang-orang yang ada didalam lingkungannya.Adapun menurut Nuraini (2013:97) lingkungan kerja adalah segala sesuatu yang ada disekitar karyawan dan dapat mempengaruhi dalam menjalankan tugas yang diembankan kepadanya misalnya dengan adanya Air Conditioner (AC), penerangan yang memadai dan sebagainya.

Menurut Nitisemito, (1982:183) lingkungan kerja disini adalah segala sesuatu yang ada di sekitar para pekerja dan yang dapat mempengaruhi dirinya dalam melakukan tugastugas yang dibebankan. Adapun faktor lingkungan fisik yang harus diperhatikan oleh perusahaan dalam upaya meningkatkan semangat dan gairah kerja antara lain: kebersihan, pertukaran udara, penerangan, ketenangan, keamanan dan kebisingan.Berdasaran penjelasan di atas dapat disimpulkan bahwa lingkungan kerja adalah segala sesuatu yang ada dan terjadi disekitar karyawan atau pegawai serta dapat mempengaruhi pegawai dalam menjalankan tugas yang diembannya. Jenis-Jenis Lingkungan Kerja secara rinci dijelaskan bahwa: 


\section{Journal Publicuho}

ISSN 2621-1351 (online), ISSN 2685-0729 (print)

1. pengertian lingkungan kerja fisik menurut Nitisemito (2002:183), lingkungan kerja fisik adalah segala sesuatu yang ada disekitar karyawan,yang dapat mempengaruhi karyawandalam menjalankan tugas-tugas yang dibebankan.

2. Lingkungan kerja nonfisik mencangkup semua keadaan yang terjadi berkaitan dengan hubungan kerja, baik hubungan dengan atasan maupun hubungan sesama rekan kerja, ataupun hubungan dengan bawahan (Sedarmayanti (2001:31).

ada 2 jenis faktor-faktor yang digolongkan kedalam lingkungan kerja yaitu faktor fisik dan faktor non fisik. Faktor fisik yang tercakup dalam lingkungan kerja, antara lain terdiri dari: 1) Pewarnaan; 2) Kebersihan; 3) Teknologi; 4) Peralatan kerja. Kemudian faktor lingkungan kerja nonfisik antara lain terdiri dari beberapa aspek, yaitu: 1) Hubungan dengan atasan; 2) Hubungan dengan rekan kerja; 3) Keamanan kerja; 4) Kecocokan dengan pekerjaan; dan 5) Otonomi dalam melakukan pekerjaan (Nitisemito (1982:184).

\section{Hubungan Promosi Jabatan terhadap Kepuasan Kerja}

Promosi jabatan merupakan salah satu variabel yang memiliki hubungan yang erat dengan kepuasan kerja, di mana kepuasan kerja seseorang dapat dipengaruhi oleh promosi jabatan.Hasil penelitian yang dilakukan oleh Asmawiyah (2015) menunjukan bahwa pengembangan karir atau promosi jabatan berpengaruh positif dan signifikan terhadap kepuasan kerja.Namun hal itu berbeda dengan hasil penelitian yang dilakukan olehMuhammad Ehsan Malik et al (2012:8) yang menemukan bahwa promosi jabatan berpengarug tidak signifikan terhadap kepuasan kerja.

\section{Hubungan Lingkungan Kerja terhadap Kepuasan Kerja}

Lingkungan kerja merupakan salah satu variabel yang memiliki hubungan yang erat dengan kepuasan kerja, di mana kepuasan kerja seseorang dapat dipengaruhi oleh lingkungan tempatnya bekerja.Hasil enelitian yang dilakukan oleh Asmawiyah (2015) menunjukan bahwa lingkungan kerja berpengaruh positif dan signifikan terhadap kepuasan kerja.Selain itu, penelitian yang dilakukan oleh Muzdalifah (2017) juga mengungkapkan bahwa lingkungan kerja berpengaruh positif dan signifikan terhadap kepuasan kerja.

\section{Hipotesis Penelitian}

Hipotesis dalam penelitian ini adalah sebagai berikut:

$\mathrm{H} 1$ : Promosi jabatan dan lingkungan kerja secara simultan berpengaruh positif dan signifikan terhadap kepuasan kerja guru pada SMAN 6 Kendari

H2 : Promosi jabatan berpengaruh positif dan signifikan terhadap kepuasan kerja guru pada SMAN 6 Kendari

H3 : Lingkungan kerja berpengaruh positif dan signifikan terhadap kepuasan kerja guru pada SMAN 6 Kendari 


\section{METODOLOGI}

\section{Populasi Dan Sampel}

Populasi dari penelitian ini adalah seluruh seluruh Guru PNS pada SMA Negeri 6 Kendri yang berjumlah 57 orang pada tahun 2018. Teknik pengambilan sampel yang digunakan dalam penelitian ini adalah sampel jenuh. sehingga jumlah sampel dalam penelitian ini adalah keseluruhan jumlah populasi yang berjumlah 57. Jenis data dalam penelitian ini adalah data kualitatif dan kuantitatif. Adapun sumber data adalah data primer dan data sekunder. Data primer merupakan sumber data yang langsung memberikan data kepada pengumpul data, Sugiyono $(2014,193)$. Adapun data sekunder merupakan sumber yang tidak langsung memberikan data kepada pengumpul data, misalnya lewat orang lain atau lewat dokumen. Data sekunder yang diperoleh dalam penelitian ini berupa informasi tertulis, dokumentasi dan laporan-laporan yang berkaitan dengan data yang diteliti.

Metode pengumpulan data dalam penelitian ini adalah metode angket atau kuesioner dan metode dokumentasi. Sugiyono $(2014,199)$ menyatakan bahwa kuesioner merupakan teknik pengumpulan data yang dilakukan dengan cara memberi seperangkat pertanyaan atau pertanyaan tertulis kepada responden untuk dijawabnya. Sementara etode dokumentasi merupakan metode pengumpulan data dan informasi yang dilakukan dengan cara melihat, membaca dan mempelajari kemudian mencatat data tertulis yang berhubungan dengan penelitian.

Teknik analisis data yang digunakan dalam penelitian ini adalah analisis statistik deskriptif dan analisis linear berganda. Statistik deskriptif, yaitu statistik yang dipergunakan untuk menganalisa data dengan cara mendeskripsikan atau menggambarkan data yang telah terkumpul sebagaimana adanya tanpa bermaksud membuat kesimpulan yang berlaku untuk umum atau generalisasi (Sugiyono, 2014:206). Analisa ini berupaya mengungkapkan fenomena sesuai dengan maksud responden tentang variable yang diteliti. Analisis regresi linear berganda digunakan untuk mengetahui pengaruh variabel bebas terhadap variabel terikat, baik itu secara parsial maupun secara simultan.

\section{HASIL DAN PEMBAHASAN}

\section{Hasil Analisis dan Pengujian Hipotesis}

Dalam penelitian ini, untuk menjawab permasalahan dan hipotesis yang diajukan maka analisis data yang digunakan yaitu analisis linear berganda. Hasil analisis regresi linear berganda yang menguji pengaruh variabel Promosi Jabatan $\left(X_{1}\right)$ dan Lingkungan Kerja $\left(X_{2}\right)$ terhadap variabel Kepuasan Kerja Guru (Y) pada SMAN 6 Kendari dapat dilihat pada Tabel 1. 
Tabel 1. Path Coefficient

\begin{tabular}{lllll}
\hline Variabel bebas & Koefisien Parsial & $\mathbf{t}_{\text {hitung }}$ & $\mathbf{t}_{\text {sig }}$ & Ket \\
\hline Promosi Jabatan $\left(X_{1}\right)$ & & & & \\
Lingkungan Kerja $\left(X_{2}\right)$ & 0,273 & 3,498 & 0,013 & Sig \\
\hline Konstanta $(a)$ & 0,191 & 2,332 & 0,019 & Sig \\
R & 0,509 & & & \\
R Square $\left(R^{2}\right)$ & 0,403 & & & \\
F hitung & 0,563 & & & \\
$F_{\text {sig }}$ & 5,250 & & & \\
\hline
\end{tabular}

Sumber: Data asli diolah pada SPSS, 2018

Berdasarkan dari tabel diatas dapat diiterprestasikan sebagai berikut:

1. Nilai $R$ (angka koefisien determinan) 0,403 menujukan hubungan yang kuat antara promosi jabatan $\left(\mathrm{X}_{1}\right)$, dan Lingkungan kerja $\left(\mathrm{X}_{2}\right)$ terhadap kepuasan kerja guru $(\mathrm{Y})$ pada SMAN 6 Kendari

2. Nilai koefisien determinan $\left(R^{2}\right)$ Sebesar 0,563 menujukan bahwa besaran pengaruh langsung variabel promosi jabatan $\left(X_{1}\right)$, dan Lingkungan kerja $\left(X_{2}\right)$ terhadap kepuasan kerja guru $(Y)$ adalah $56,3 \%$ sehingga sisanya $43,7 \%$ adalah pengaruh variabel lain yang tidak teliti dalam pada penelitian ini. Hubungan ini secara statistika tergolong kuat sebagaimana yang dikemukakan oleh sugiyono (2007) bahwa hubungan variabel yang tergolong kuat adalah sebesar 0,80 - 100. Nilai $R^{2}$ sebesar 56,3\% menujukan semakin kuatnya pengaruh variabel bebas yaitu promosi jabatan $\left(X_{1}\right)$ dan lingkungan kerja $\left(X_{2}\right)$ Terhadap Variabel Terikat Kepuasan Kerja Guru (Y).

H1 : Promosi Jabatan dan Lingkungan Kerja secara Simultan Berpengaruh Positif dan Signifikan terhadap Kepuasan Kerja Guru

Variabel promosi jabatan $\left(X_{1}\right)$ dan lingkungan kerja $\left(X_{2}\right)$ secara stimultan (bersama sama) berpengaruh positif dan signifikan terhadap kepuasan kerja guru ( $Y$ ) pada SMA Negeri 6 Kendari. hal ini dapat dilihat melaui nilai probalitasnya Fsig sebesar 0,008 < taraf signifikan $a=0.05$. Hal ini dapat di artikan bahwa hipotesis pertama yang diajukan dalam penelitian ini dapat diterima.

\section{H2 : Promosi Jabatan berpengaruh positif dan signifikan terhadap Kepuasan Kerja Guru}

Hasil analisis pengaruh secara parsial variabel promosi jabatan menunjukkan nilai $\dagger$ hitungsebesar 3,498 dengan tingkat signifikansi sebesar 0.013. Nilai signifikansi tersebut lebih kecil dari nilai a sebesar 5\% (0.05) sehingga menunjukan bahwa variabel promosi jabatan berpengaruh positif dan signifikan terhadap kepuasan kerja guru pada SMA Negeri 6 Kendari sehingga hipotesis kedua dalam penelitian ini dapat diterima.

\section{H3 : Lingkungan Kerja berpengaruh positif dan signifikan terhadap Kepuasan Kerja Guru}

Hasil analisis pengaruh secara parsial variabel lingkungan kerja menunjukkan nilai $\mathbf{t}$ hitung sebesar 2,332 dengan tingkat signifikansi sebesar 0,019. Nilai signifikansi tersebut 
ISSN 2621-1351 (online), ISSN 2685-0729 (print

Volume 3 Number 3 (August-October), (2020) pp.349 -360

Muhamad Masri

DOI: 10.35817/jpu.v3i3.12352

lebih kecil dari nilai a sebesar 5\% (0.05) sehingga menunjukan bahwa variabel lingkungan kerja berpengaruh positif dan signifikan terhadap kepuasan kerja guru pada SMA Negeri 6 Kendari sehingga hipotesis ketiga dalam penelitian ini dapat diterima.

\section{PEMBAHASAN}

Promosi Jabatan dan Lingkungan Kerja secara Simultan Berpengaruh Positif dan Signifikan terhadap Kepuasan Kerja Guru

Hasil penelitian ini menunjukan bahwa secara simultan promosi jabatan dan lingkungan kerja berpengaruh positif dan signifikan terhadap kepuasan kerja. Pengaruh positif memiliki arti bahwa peningkatan promosi jabatan dan lingkungan kerja searah dengan peningkatan kepuasan kerja. Adapun pengaruh signifikan memiliki arti bahwa tingkat kepercayaan terhadap pernyataan bahwa secara simultan promosi jabatan dan lingkungan kerja berpengaruh terhadap kepuasan kerja sudah sangat baik dan dapat dipercaya. Berdasarkan penjelasan di atas dapat disimpulkan bahwa pemberian promosi jabatan yang baik dan lingkungan kerja yang nyaman dapat meningkatkan kepuasan kerja guru pada SMA Negeri 6 Kendari.

Hasil penelitian ini mendukung hasil penelitian yang dilakukan Asmawiyah (2015) yang menemukan bahwa pengembangan karir atau promosi jabatan dan lingkungan kerja berpengaruh signifian terhadap kepuasan kerja.

\section{Pengaruh Promosi Jabatan terhadap Kepuasan Kerja Guru}

Hasil penelitian ini menunjukan bahwa promosi jabatan berpengaruh positif dan signifikan terhadap kepuasan kerja. Pengaruh positif dapat diartikan bahwa promosi jabatan memiliki pengaruh yang searah terhadap kepuasan kerja, sementara pengaruh signifikan berarti bahwa tingkat kepercayaan terhadap kebenaran dari pernyataan bahwa promosi jabatan berpengaruh terhadap kepuasan kerja dapat dipercaya. sehingga peningkatan promosi jabatan dapat berpengaruh pada meningkatnya kepuasan kerja guru serta penurunan promosi jabatan dapat berpengaruh pada menurunnya kepuasan kerja guru. Hal ini dapat dilihat pada tanggapan responden yang sudah sangat baik/tinggi terhadap seluruh indikator promosi jabatan, khusunya pada pernyataan bahwa atasan selalu menghargai kerja keras saya, tanggapan responden mencapai angka 4,52.

Hasil penelitian ini berbeda dengan hasil penelitian yang dilakukan oleh Muhammad Ehsan Malik et al (2012:8) yang menemukan bahwa promosi jabatan berpengaruh tidak signifikan terhadap kepuasan kerja. Namun di sisi ain, hasil penelitian ini memperkuat hasil penelitian yang dilakukan oleh Asmawiyah (2015) yang menemukan bahwa pengembangan karir berpengaruh positif dan signifikan terhadap kepuasan kerja.

\section{Pengaruh Lingkungan Kerja terhadap Kepuasan Kerja Guru}

Hasil penelitian ini menunjukan bahwa lingkungan kerja berpengaruh positif dan signifikan terhadap kepuasan kerja. Pengaruh positif dapat diartikan bahwa lingkungan 


\section{Journal Publicuho}

ISSN 2621-1351 (online), ISSN 2685-0729 (print)

Volume 3 Number 3 (August-October), (2020) pp.349-360

Accredited SINTA SK.NOMOR 28/E/KPT/2019

memiliki pengaruh yang searah terhadap kepuasan kerja, sementara pengaruh signifikan berarti bahwa tingkat kepercayaan terhadap kebenaran dari pernyataan bahwa lingkungan kerja berpengaruh terhadap kepuasan kerja dapat dipercaya. sehingga perbaikan ingkungan kerja dapat berpengaruh pada meningkatnya kepuasan kerja guru serta memburuknya lingkungan kerja dapat berpengaruh pada menurunnya kepuasan kerja guru. Hal ini dapat dilihat pada tanggapan responden yang sudah sangat baik/tinggi terhadap seluruh indikator lingkungan kerja, khusunya pada pernyataan bahwa Hubungan yang terjalin antara sesama rekang kerja sangat baik, tanggapan responden mencapai angka 4,46 .

Hasil penelitian memperkuat hasil penelitian yang dilakukan oleh Asmawiyah (2015) dan juga peneitian yang dilakukan oleh Muzdalifah (2017) yang menemukan bahwa lingkungan kerja berpengaruh positif dan signifikan terhadap kepuasan kerja.

\section{KESIMPULAN}

Berdasarkan hasil penelitian dan pembahasan tentang factor-faktor yang mempengaruhi kepuasan kerja guru PNS pada SMA Negeri 6 Kendari, maka dapat ditarik beberapa kesimpulan sebagai berikut:

1. Promosi jabatan dan lingkungan kerja merupakan faktor-faktor yang mempengaruhi kepuasan kerja guru PNS pada SMA Negeri 6 Kendari. Sehingga kepuasan kerja guru PNS pada SMA Negeri 6 Kendari dapat dipengaruhi oleh promosi jabatan dan kondisi lingkungan kerja.

2. Promosi jabatan berpengaruh positif dan signifikan terhadap kepuasan kerja guru PNS pada SMA Negeri 6 Kendari. Artinya semakin tinggi promosi jabatan maka dapat meningkatkan kepuasan kerja guru PNS pada SMA Negeri 6 Kendari.

3. Lingkungan kerja berpengaruh positif dan signifiakn terhadap kepuasan kerja guru PNS pada SMA Negeri 6 Kendari. Artinya perbaikan lingkungan kerja dapat meningkatkan kepuasan kerja guru PNS pada SMA Negeri 6 Kendari.

\section{SARAN}

Berdasarkan hasil penelitian dan pembahasa, maka penliti menyarankan beberapah hal sebagai berikut:

1. Memperbaiki prosedur promosi jabatan pada SMA Negeri 6 Kendari. Melihat tanggapan responden pada variabel promosi jabatan, maka disarankan kepada pihak SMA Negeri 6 Kendari agar memperbaiki promosi jabatan dengan cara pemberian promosi jabatan yang dilakukan dengan adil sesuai kemampuan guru. 
2. Memperbaiki lingkungan kerja pada SMA Negeri 6 Kendari. Melihat tanggapan responden pada variabel lingkungan kerja, maka disarankan kepada pihak SMA Negeri 6 Kendari agar memperbaiki lingkunan kerja dengan cara menggunakan teknologi yang canggih dan modern.

3. Penelitian ini hanya fokus pada analisis faktor - faktor yang mempengaruhi kepuasan kerja guru PNS pada SMA Negeri 6 Kendari yang terdiri dari variabel bebas (promosi jabatan dan lingkungan kerja) sehingga belum mampu menjelaskan secara komprehensif dari semua faktor yang mempengaruhi kepuasan kerja guru PNS pada SMA Negeri 6 Kendari maka disarankan kepada peneliti selanjutnya untuk meneliti variabel gaya kepemimpinan, budaya organisasi dan pemberian reword. 


\section{Journal Publicuho}

ISSN 2621-1351 (online), ISSN 2685-0729 (print)

Volume 3 Number 3 (August-October), (2020) pp.349-360

\section{DAFTAR PUSTAKA}

Eka Gorby Setia Jaya. 2015. Pengaruhpromosi Jabatan Dan Motivasikerja Terhadap Kepuasan Kerja Agen Pt. Asuransi Jiwasraya Magelang Branch Office

Ghozali, Imam. 2006. Aplikasi Analisis Multivariate dengan program SPSS. Semarang : UNDIP

Handoko, T Hani. 2001. Manajemen Personalia dan Sumberdaya Manusia, Edisi Kedua. BPFE, Yogyakarta. Stephen

Hasibuan, Malayu S.P. 2002. Manajemen Sumber Daya Manusia. Jakarta: Bumi Aksara.

Hasibuan, Malayu SP. 2005. Manajemen Sumber Daya Manusia. Jakarta: BumiAksara Rosdakarya.

Handoko, T. Hani. 2009. Manajemen Personalia dan Sumberdaya Manusia. Yogyakarta : BPFE

Hoy, Wayne, K .2001. Education Administrations:Theory, Research and Practice. Singapura: Mc Graw-Hill Co.

Luthans, Fred. (2006). Perilaku Organisasi, (Alih Bahasa V.A Yuwono, dkk), Edisi Bahasa Indonesia, Yogyakarta: ANDI.

Luthan, Fred. 1998. Organisasi Behavior (Eight Edition). McGraw-Hill: Intemasional Book Company.

Manullang, M. (2004). Manajemen Personalia. Yogyakarta:Universitas Gajah Mada.

Mathis, Robert L. dan John, H. Jackson. 2008. Human Resource Management. Jakarta : Salemba Empat

Milton R.J. Salton dan Kwang-Shin Kim, 1981. Structur of Bacteria. . www.bact.wisc.edu. Departement of Baceriology University of WisconsinMadison.USA

Muhammad Ehsan Malik et al.: 2012 "The Impact of Pay and Promotion on Job Satisfaction: Evidence from Higher Education Institutes of Pakistan". American Journal of Economics June 2012, Special Issue: 6-9.

Muzdalifah. 2017, "Pengaruh Kompensasi, Lingkungan Kerja Dan Stres Kerja Terhadap Kepuasan Kerja Karyawan (Studi Kasus Pada Rumah Makan Soto Betawi Bang Udin)"

Nitisemito. 1982. Manajemen Personalia. Jakarta: Ghalia Indonesia

Nitisemito, Alex. 2000. Manajemen Personalia. Jakarta: Gahlia Indonesia.

Nitisemito, Alex, 2002 "Manajemen Sumber Daya Manusia", Cetakan Kesembilan.Edisi ke Empat, Jakarta.

Nuraini, T, 2013 "Manajemen Sumber Daya Manusia", Yayasan Aini Syam,Pekanbaru.

Rivai, Veithzal. (2004). Manajemen Sumber Daya Manusia Untuk Perusahaan: Dari Teori Ke Praktik. PT. Raja Grafindo Persada. Jakarta.

Robbins, 2006. Perilaku Organisasi. Alih Bahasa : Benyamin Molan. Edisi Kesepuluh.Penerbit PT. Indeks, Kelompok Gramedia, Jakarta.

Robbins, S.P., \& Judge, T. 2011 . Organizational behavior 14th ed.. New Jersey: Prentice Hall.

Sedarmayanti, 2007 "Manajemen Sumber Daya Manusia, Reformasi Birokrasi dan Manajemen Pegawai Negeri Sipil", PT. Refika Aditama, Bandung. 
ISSN 2621-1351 (online), ISSN 2685-0729 (print

Volume 3 Number 3 (August-October), (2020) pp.349 -360

Muhamad Masri

DOI: 10.35817/jpu.v3i3.12352

Sedarmayanti, 2012 "Manajemen Sumber Daya Manusia, Reformasi Birokrasi dan Manajemen Pegawai Negeri Sipil", PT. Refika Aditama, Bandung,EdisiRevisi.

Sugiono. 2009. Metode penelitian kualitatif dan R\&D. Bandung. Alfabeta.

Sugiyono. (2014). Metode Penelitian Bisnis (Pendekatan Kuantitatif, Kualitatif, Dan R\&D). Bandung: Alfabeta.

Supardi, 2005. Metodoogi Penelitian Ekonomi dan Bisnis, UII Press, Yogyakarta

Susilo Martoyo 2000, Manajemen Sumber Daya Manusia edisi 4 , dicetak dan diterbitkan BPFE Yogjakarta.

Sutrisno, Edy. 2009. Manajemen Sumber Daya Manusia. Jakarta: Kencana Prenada Media Group. 